\title{
GLOBALISATION AND ITS AFFECT \\ TO DEVELOPED AND DEVELOPING COUNTRIES, CASE STUDY REPUBLIC OF NORTH MACEDONIA
}

\author{
Gordana Bilbilovska ${ }^{1}$ \\ Ivana Bilbilovska ${ }^{2}$
}

DOI: https://doi.org/10.31410/ERAZ.2019.385

\begin{abstract}
Globalization is current and inevitable process, which brings good things (like capital flow, technology transfer, export) and some side effects (like pressure on domestic production, interfierence in economic policy and economic dependence of countries). Accumulation of wealth is one of globalization triggers. Half of world capital is owned by developed countries, while others are fighting to gain better position.

Asia has the fastest accumulation of wealth and development. In 2017, China was ranked first economy in the world (considering inovations). It was projected that China's GDP will double by 2020. Qatar is the ritchest country in the world with the highest living standard and third by resources of natural gas. In the second half of 20th century, Luxemburg is considered financial center. Singapour is also among the ritchest countries and lider in technological inovation.
\end{abstract}

Globalization led to coorporations controling economies, finances and technology, using developing and postsocialistic countries in accumulation of even bigger wealth. They are big enough to negotiate rules and taxes with smaller countries, and often they build monopol position in these economies. The big corporations come from the developed countries and that is why globalization contributes to wealth accumulation. This triggers the global distribution of industry as well-labour intensive industries in poorer countries, eco-unfriedly technology in less developed countries.

In addition, while people in less developed countries are struggling to survive, globalization imposes change of cultural and hystorical values. Smaller economies spend their resources without any benefit, built bigger public debt; lose jobs, bassicaly they struggle. So intervention is needed by institutions, better management, fight with coruption and criminal. These economiess have limited opportunitites for increasment of production, productivuty, and competitivnes and by that economic growth. So they need to work on the export structure with know how transfer and help of the FDI.

This paper uses methods as analyses, deduction, induction, syntezis and comparative analyses.

In further period, it is expected that the globalization will induce changes in economy and politics and progress. The question how to decrease the gap between poor and rich countries remain.

Keywords: Developing Countries, Developed Countries, Globalization, Growth.

\section{INTRODUCTION}

Globalization is a process of opening towards the world and integration influenced by domJination and power. „It is a game of interest at a higher level, a risky and conflicting game.” (Gjegozh, Kolodko, 2004, p. 13). The world is divided into countries that are influenced and countries that are influencers.

\footnotetext{
1 Faculty of Economics, University of “St.Cyril and Methodius”-Skopje, Bul.”Goce Delcev” no. 9B 1000 Skopje, Republic of North Macedonia

2 Ministry of Finance, Bul.’Dame Gruev" no.12, 1000 Skopje, Republic of North Macedonia
} 
For developed countries, globalization serves in function of modernization, liberalization, economic and political forces. Multinational companies are the ones that subordinate everything to their interests. They promote competition, efficiency, specialization, new ideas, experiences, new methods of organization, but generally, they create the base for inequality. The overall result of globalization is rich becoming richer, and the poor poorer. Corporations are motivated by high profit, affecting resources, transfers, trade and balance of payments, competitive ability.

For developing countries, globalization may be a source of limitation of sovereignty, structural dependence, subordination to the international division of labor, even exploitation. Technology transfer has the largest impact on developing countries. They are accustomed to the macro and micro level to cope with the disloyal competition of developed countries, which are the economically most organized strength of international economic relations. Underdeveloped countries are asked to give up their identity, and each step in the function of development is conditioned. So the question is - what is the benefit of globalization, when the gap between the rich and the poor countries deepens, and the potential profit is moving to foreign countries?

As a post-socialist country, the Republic of Northern Macedonia is interested in more favourable global placement. The country needs a global strategy for production development, trade and financial transactions. The greatest concearn remains the corruption, which has great impact on the business climate and investment decisions.

\section{GLOBALIZATION IN FUNCTION OF GROWTH OF DEVELOPED COUNTRIES}

Global problems give guidance, and those who lead to fulfillment of goals for countries welfare are the priority. They are transferring capital, new technology, new products, increased exports and employment of the population.

In 2017/2016, private wealth increased globaly, concentrated in the US, China, Japan, Great Britain, Germany, India, France, Canada, the Netherlands, Australia and Italy. In the political and economic world the countries of the European Union, the United States and the countries of eastern and southeastern Asia remain most influential. According to the UN classification, the happiest people live in Finland, Norway and Denmark. Within its borders, the EU is the creator of economic and social development, the development of foreign trade and partnership in the Union. They have developed economies, their education is at a high level and literacy percentage is $99 \%$.

The US is one of the most influential and powerful countries in the world. It is a big country with numerous and consumerist population, with natural resources, and at the world's top in all industries. It is also the leading country in scientific research. The Silicon Valley has a high technology concentration. The financial sector is also an important branch. The US is the main importer and exporter of goods in the world and main trading partner of many countries. The level of education is lower compared to other developed countries.

China is also a large and rich country with raw materials, metals and energy products. China is also oriented towards economic reforms that are oppening this economy to the world. Chinese market economy is very interesiting considering the influence of the Communist Party of China. Still it advocates freedom in economic cooperation and is one of the largest producers and consumers in the world. China is world trade leading force, an implementator of new strategies. 
Chinese companies are doing acquisition and merge with foreign companies, buying everything that benefits them, but they are clashing with the competition as well.

China's growth is due to the market. However, China achieved the lowest growth in the last three decades in the first quareter of 2019. The result is the Government's effort to settle debt, as well as the effects of the trade war with the United States. This situation has consequences for the global market as well. However, according to Gallup International, most of the inquiries in 2019 consider China as the world economic leader.

India is also big economy, with global economy influence. The secret of its success is cheap labor, natural resources, innovation, software technology, social development through the transformation of society and the formation of institutions that support the market economy.

Russia has clear ideas in its development. It is rich in natural wealth. It is aslo one of the largest industry in the world. Russia has a huge market and a large increase in the living standard of the population over the past years. It is most likely becoming one of the leading economies in Europe. There are also large multinational corporations' origing from Russia and China.

Qatar is also one of the leading economies in the world. It has 1.7 million inhabitants and large reserves of oil and natural gas. Qatar focuses on the development of technology. In recent years, the country invested in tourism as well. Consumer culture prevails in the country. Unemployment is just $0.1 \%$, and jobs are guaranteed. The education and health care are free services.

Singapore is a rich country in which technology, manufacturing and the financial sector are advancing. It has a stable economy.

Based on prosperity index from 2017 Norway is the richest country, followed by Switzerland, Denmark, New Zealand, Sweden, Canada, Australia, the Netherlands, Finland and Ireland. For the prosperity index, 89 factors were compared, among them GDP per capita, number of employees, how many people feel good in life, and 8 categories were applied: economy, entrepreneurship, education, health, safety, personal freedom, social capital, governance. (www. biznisvesti.mk).

The number of billionaires in the world increased in 2017. There were 1226 billioners in 58 countries in the world, most of them in US (425), Asia (315), Europe (310), South America (90), and in the Middle East and Africa (86) (www. Blic.rs). Mostly these are the owners of several telecom and IT networks.

Developed countries have high incomes and a high average life span. In developed countries, unemployment is in small percentage, as well as the level of poverty. The education system is at high level as well. Industry and production are constantly progressing.

The transnational companies, origing from developed countries, were located in their mother countries, until the 1980s. Since the mid 1980s, their production started to be allocated in underdeveloped countries, utilizing local resource and work force, and throught that affecting reallocation of resources in the world. Their concentration in developed countries has the effect of developing technology, stimulating the development of production and distribution, competing, maximizing profits, under the law of accumulation and having success in the global market. 
Large corporations have their own factories, plants, workers, refineries, banks in several countries in the world, whose capital exceeds the power and influence of many countries. They continue to conquer new markets, enhance competitiveness, control raw materials prices, even influence countries sovereignty and build new rules on the global market. They introduce the vision and structure of production, and by selling their products, they invest themselves in criteria and methods inherent to globalist orientation. The pursuit of profit leads them to wide proportions to the integration processes. They influence the international movement of capital.

Large corporations are widespread throughout the world and control the world economy. There are financial transactions and investment processes, multiplying international activities by trillions of dollars and an economic power in the world. They penetrate into new spaces where they benefit. There is also a combined ownership of a part of the means of production from various countries through the branches of multinational companies. These companies mostly export capital, but also export of goods is maintained. They are a segment of progressive development potentials as they spread the new technique, organization of work and management, ideas, production experience, increased exports, increased accumulation, capacity optimization, international division of labor and international movement of capital, employment. The economic and financial power of large capital is felt everywhere, where consumers' habits and behavior are known.

The basis is profit, because the accumulation law requires them to maximize profits. When they succeed in their own country, only plants around the world ensure the placement of final products. Supply of raw materials and cheap labor, low taxes, and liberal environmental regulations are to be found in underdeveloped countries. The companies from developed countries sell the final products, dictate the competition and make the profit. „For example, in Russia for a long time there is INGOSTRAH which has branches in the United States, Holland, Great Britain, France, Austria, Germany, Armenia, Azerbaijan, Moldova, Latvia, Estonia, Lithuania, Belarus, Ukraine, Turkmenistan, and NAFTA-Moscow has daughter companies in developed western countries. (Sreten Sokic 2003, page 102).

International companies have large impact on regulation - on global frameworks and state legislation as well, including economic and development policy strategies. The prospect of globalization is great economic power of multinational corporations, among which are banks that control the world economy.

The World Economic Forum (WEF) was held in Davos in January 2018, where new strategies were elaborated. President of Serbia Aleksandar Vučić has been in favor of regional cooperation in the function of regional and harmonious development of the region, as well as integration to the European Union. It is known that EU membership requires approximation of the asspiring members economy to the EU economies, to the per capita income, prices, inflation and interest rates. That is why reforms are needed for these countries to get closer to the developed economies. Foreign direct investments are needed as well, that will bring additional capital in countries that have good geostrategic position and cheap but well-trained labor force. Companies from the region are uncompetitive, failing to achieve a critical level of development, and the EU can hardly accept a country with a lower GDP from the least developed member state of the Union.

US President Donald Tramp pointed out that the rapid growth of the US economy is in the function of creating better living conditions. There were also some comments at the expense of underdeveloped countries. The rich have reached the ceiling, and the question is whether they will 
stop or will continue to be motivated for new and emerging challenges in the world. Motivation for prestige does not disappear even when their natality is continuously decreasing, when they have a greater share of the elderly population.

This year in Davos (2019), it was pointed out that the world economy will increase by 3.5\%. Although developed countries have a priority in economic cooperation and they have their own problems, which are still less than those in underdeveloped countries. They have insatiable hunger for capital and their motive is investment in other countries when they derive from economic benefits, among which are: "expanding their economically most profitable business activities; expanding the market with its own products and improving its own position on it; favorable use of natural resources; possibilities of transfer of profit and repatriation of capital; expansion of the raw material and production base; placement of already acquired technology; possibility of extra profit in the long run; acceptance of the principle of taxation of profits and favorable possibilities for reinvestment; legal guarantees to a foreign investor in the legal protection of the invested and created; the expansion of experimental areas for scientific-technical testing and the acquisition of new technology; the use of cheap labor in his own country "(Sreten Sokić, 2003, p. 96).

Developed countries goals are increasing the production, placement and consumerism on the globall market.

\section{GLOBALIZATION AND DEVELOPING COUNTRIES}

Developed countries have negative effects when pushing domestic products into the market and blending in the economic policy of less developed countries, when they create economic dependence and control. Undeveloped countries are over-indebted, have demographic explosions, unemployment and a large percentage of poor population. In the process of their economic development they merge in the template that multinational companies and international institutions create to cope with globalization process. There are capital squandering and management under other rules, there are speculative transfers that provide quick profits for companies from developed countries, without direct investment in production in underdeveloped countries. They are asked to give up their identity, and for each step they make a number of tasks that they have to fulfill conditions them. All this is in the function of deteriorating living conditions in developing countries, and their historical and systemic heritage, dominant culture and value preference should not be released. This creates a psychological tension with the population, so the question is - what can be the benefit of globalization to them. Their inferior dimension is the operation of the world capital and the mechanism of its reproduction, the policies of financial institutions that have a dominant role, and people are struggling to survive. The gap between the rich and the poor is steadily increasing ( $82 \%$ of the generated capital belongs to $1 \%$ of the richest, and half of the world's population is 3.7 billion people struggling to survive), while the super-rich accumulate global wealth.

Developing countries need to know that for their economic recovery they need to have a solid development strategy, with goals in line with their economic, technological and democratic development. They need free trade, as well as foreign direct investments in the function of addressing the problem of poverty, as well as fair distribution. A large number of businesses disappear due to the actions of external competition, which is a dictation of large-scale capital. There is also the effect of global and regional shocks that are causing changes in the global market, which deepen the crisis in developing countries. 
Developing countries need to create a new economy, where farming should be focused on other activities with more productivity. Industry development increases employment, attracts modern technology and capital, high productivity and favorable competitiveness in the global market. Exports are developing, they can regulate debts and improve their position in the global market. They need a high degree of processing of export products, as well as in the best way combining the factors of production and modernization of the economy. The countries that have done this have achieved development and are at the top of the world's wealthiest nations: Hong Kong, South Korea, Qatar, Singapore, Luxembourg, Mexico and Brazil. They have strong institutions, a liberalized and open economy, developed infrastructure, quality education and the rule of law.

The development strategy should have a lasting and stable export orientation and linking trade agreements, but also to correct mistakes from the past, orientation for efficient use of human resources and natural resources. In the function of increasing competitiveness in the world market, they should have a national strategy, and for export they should look for new markets and come to foreign investments, which are in function of increasing employment. In a competitive struggle with developed countries, orientation should be towards specific policies, designed reforms should guide the economy. A country that is not competitively capable and unsuccessful should work to increase the quality of its products, productivity, economy, market organization, knowledge, and marketing, to focus on what they know best. Governments should adopt functional strategies that should generate growth. Interest should be their restructuring of the financial sector, which would enable them to solve problems and macroeconomic balance.

Corporate restructuring would solve problems in the company. They should apply international standards, international visions and affirmation of rational decision-making, and produce what consumers want, with an emphasis on the quality of products and services. They should perform their activity successfully and always have a market that verifies their work. They need help and support from developed countries around the world to find ways to help them to accept development messages because poverty, low levels of education, low work qualifications, poor nutrition, an unhygienic environment, and poor housing conditions are difficult to tolerate.

Foreign direct investment should be part of the reforms for economic development and improvement of the international competitiveness of developing countries. In order to achieve this, they should have advanced technology, economies of scale, labor productivity, respect for quality standards, well-developed marketing, high level of processing of export products, servicing, etc. They need to combine production factors, based on natural resources, labor, capital, technology, management and marketing, to work on modernizing the economy, reducing costs and strengthening competitiveness. In poor countries, there is corruption (Somalia, Syria, Libya, Sudan, Iraq, Cambodia, etc.), which affects the quality of healthcare, education and other institutions in the country.

The fact is that the poorest countries are located in areas with a tropical climate, where there are severe living conditions that affect the development of agro-culture, tropical diseases, and high temperatures contribute to the development of parasites, viruses and bacteria. Demographic explosion slows down economic development and does not allow them to meet basic human needs. They are over-indebted, have great unemployment and an expansive type of age structure with young people. 


\section{REPUBLIC OF NORTH MACEDONIA IN THE PROCESS OF GLOBALIZATION}

Globalization exists and is progressing independently of will and multinational companies play a game of interest, they want competition because they have advantages and they succeed everywhere. The Republic of Northern Macedonia is a small country that is fighting for its position on the global market. After independence, the market economy with temptations and difficulties passed. Transformation of ownership, entrepreneurial spirit and free competition were supposed to increase the efforts of businesspersons to modernize production, increase labor productivity and product exports, and improve the standard of living of the population.

Institutions with a new organization were built. "These include the rules relating to WTO trade liberalization, environmental protection standards and policies, accepted from the ON implementation plans, and sanitary standards that are being fulfilled under the WHO protector with the aim of protecting against epidemics." (Gžegož, Kolodko, 2004, p. 27). Reforms in trade liberalization and capital redress have not yielded results; a slow rise in living standards has provoked the discontent of the population. Inflation with declining production has created unemployment and social problems and great internal and external debt.

Although it was aimed at improving the competitiveness of North Macedonian products, there is still limited competitiveness of North Macedonian products and services. Association of companies is aimed at improving the competitiveness of Macedonian products and services. Laws were adopted, institutions were established, liberalization in the foreign trade regime was carried out, quotas for import and export of certain products were abolished, and the level of customs duties was reduced, price liberalization was introduced.

ISO standards for quality of products and services are applied. The tax situation is adjusted to the real situation. Fighting corruption and reducing the gray economy is needed. It should be done on innovations. Insufficient representation of foreign banks is the reason for underdevelopment of the banking sector, which is maintained with high interest rates. Importance is also an effective way of attracting foreign investments in the function of increasing and changing the structure of exports of products with a higher added value. Foreign investment creates a new production image, GDP growth, structural changes in the labor force from agriculture to industry and services.

In the function of foreign investments, the Republic of Northern Macedonia offers advantages: cheap resources, cheap and educated workforce, quality non-metallic reserves, a central place in the Balkans, as well as connection with the European Union markets.

Economy is weak to protect ourselves from external activity, because we are import dependent, we produce products with low degree of finalization, using obsolete technology and low added value. We need open international cooperation, as well as a stable legal system, to learn a lesson for a successful economy. The biggest trading partner are the EU countries. In the second place are the countries of the region.

Coverage of imports by export in foreign trade was: $63,72 \%$ in $2011,61,56 \%$ in $2012,64,94 \%$ in $2013,67,8 \%$ in 2014 , and 70,15 in $2015 \%, 2016$ is 70.8\% and the first frequent month of 2017 is 73.7\%. (CBS: 2012/2013, 2014, 2015, 2016, 2017) 
The country has a deficit in exchange with the countries of the region, and there are potentials for increasing foreign trade. The contribution to economic development is the development of regional cooperation. Therefore, the objectives and strategies for each market should be defined and their interdependence envisaged, and expertise should determine the policy, strategy and understanding of the competitiveness factor.

The Republic of Northern Macedonia should continue with the liberalization of foreign trade in the region. It is necessary to increase the trade in agricultural products.

The country's largest company is Okta from the oil business. T-mobile from telecommunications is successful. Companies with a large number of employees and high income are from electrical production, black and non-ferrous metallurgy, pharmacy, construction, etc. For accelerated growth, effective co-operation is important in investing, increasing employment and productivity. Non-trade barriers are a problem for Macedonian exporters, they are not regulated by WTO rules.

Companies should endure competition by selling the best products, to be adapted to world standards, productivity, organization of performance and knowledge. They should monitor economic trends in the world and pay attention to extra-economic factors. For economic development, the quality of education is important.

\section{CONCLUSION}

The purpose of globalization should be to move towards a better life of all people in the world. However, only a handful of rich countries benefit from globalization (25). There are 20 poor countries in the world (19 African and Afghanistan). The gap between the rich and the poor countries is deepening and questioning their sovereignty and national culture.

Today, in the economic and political fields there is the power of the trinity of developed countries: the countries of the European Union, the countries of eastern and southeastern Asia and the United States.

Of the 10 countries in the world based on all ranking categories in 2017, Norway ranks first (eight years in a row). Next are Switzerland, Denmark, New Zealand, Sweden, Canada, Australia, the Netherlands, Finland and Ireland. At the top of the rich countries are Qatar, Luxembourg and Singapore. The most powerful countries in the world are the United States, Russia, China, England and Germany.

Developing countries are struggling with problems. They have low incomes, and are dependent on prices dictated by developed countries in the world. They are overdue, have a demographic explosion and great unemployment. Economic development imposes a template for a multinational company and an international institution, capitalist capitalism and governance under other rules. Their development strategy should be adapted to the richness, resources, comparative advantages and vision where it wants to develop.

The Republic of Northern Macedonia is a small country that needs to fight for a better position in the global market, improving the competitiveness of products and services. Even today, the cheapest products with low added value are in the export. For economic development, it needs 
regional cooperation and to implement a set of reforms for economic liberalization, i.e. open international cooperation, as well as a stable legal system, to learn a lesson for a successful economy.

In order for globalization to make sense, economic development should be in the function of the dignity and equality of all people in the world.

\section{REFERENCES}

[1] Bilbilovska,G.(2006), Economic statistics, Facutlty of Economics, Skopje, pages 323-330

[2] Grzegorz, Kolodko. (2004), Globalization and development perspectives for development of postsociaslit countries, Institut of Economics, Magor DOO, Skopje, pages 13-28, 73-94

[3] State Statistics Office. (2013, 2014, 2015, 2016, ) Statistics Annual, Skopje 2013, pages 501505, 2014 pages 525-528, 227-247 and 2015, pages 553-556, 2016, pages 550, 552, 553, 554, 547.

[4] State Statistics Office: Foreign trade of Republic of Macedonia, January-June 2017, no. 7.1.17.10, pages 3-10

[5] Malcom, Waters. (2003), Globalization, Instutute for Democracy, solidarity and civil society, Skopje, pages 39-68, 106-132

[6] Sreten Sokić. (2003), Economy of tranzition, Zavet, Belgrade, pages 94-103

[7] Held, Davide. Antony, Mekgru. (2010), Management of globalization: power, authority and global management, Akademski pečat, Skopje, page 2-6, 28-34

[8] www. blic.rs

[9] www.biznisvesti.mk 